\title{
UMA NOVA ESPÉCIE DE CLINODIFLOSIS KIEFFER (DIPTERA, CECIDOMYIIDAE) ASSOCIADA COM MELISSA OFFICINALIS LINNAEUS (LABIATAE) NO BRASIL
}

\author{
Valéria Cid Maia $^{1}$
}

\begin{abstract}
A NEW SPECIES OF CLINODIPLOSIS KIEFFER (DIPTERA, CECIDOMYIIDAE) ASSOCIATED WITH MELISSA OFFICINALIS LINNAEUS (LABIATAE) IN BRAZIL. Clinodiplosis melissae, sp.n. (typelocality - BRAZIL: Rio de Janeiro, Maricá) associated with Mellissa officinalis is described from larvae, pupae, male and female.

KEY WORDS. Diptera, Cecidomyiidae, Clinodiplosis, new species, Melissa officinalis
\end{abstract}

Clinodiplosis Kieffer, 1895 é um gênero cosmopolita, que inclui formas micófagas, fitófagas e galhadoras (GAGNÉ, 1989). As espécies deste gênero ocorrem em diversas famílias de plantas, sendo este o seu primeiro registro em Labiatae, na região Neotropical.

\section{Clinodiplosis melissae, sp.n.}

Figs 1-12

Adulto. Comprimento total: 2,1-3,4 mm $(\mathrm{N}=4)$. Cabeça: olhos com facetas circulares. Pico pós-vertical presente. Antena com 12 flagelômeros, binodais e tricircunfilares no macho e cilíndricos na fêmea, ornados como nas figuras 1 e 2; escapo medindo 1,0-1,3 vezes o comprimento do pedicelo e com 1,0-1,3 vezes o seu próprio diâmetro; flagelômero I com 1,7-3,5 vezes o comprimento do escapo, medindo 3,0-3,5 vezes o seu próprio diâmetro. Peças bucais: frontoclípeo com várias cerdas, labro triangular, alongado, com três pares de cerdas longas; hipofaringe triangular, alongado, com a margem do terço apical setulosa; labelo alongado, convexo, com seis cerdas; palpo com quatro artículos: o primeiro curto com três ou quatro cerdas, os restantes cilíndricos e alongados; o segundo com cerca de 1,5-2,5 vezes o comprimento do primeiro, medindo 2,2-3,1 vezes o seu próprio diâmetro e com cinco a seis cerdas; o terceiro com cerca de 1,0-1,3 vezes o comprimento do segundo, medindo 2,7-4,4 vezes o seu próprio diâmetro e com seis a nove cerdas; o quarto com cerca de 1,1-1,5 vezes o comprimento do artículo precedente, medindo 4,3-4,7 vezes o seu próprio diâmetro e com cinco a sete cerdas. Tórax: comprimento da asa 1,9-2,4mm; nervuras alares como na figura 3. Escuto com duas

1) Museu Nacional do Rio de Janeiro, Quinta da Boa Vista, 20940-040 Rio de Janeiro, Rio de Janeiro, Brasil. Bolsista da CAPES. 
fileiras irregulares de cerdas dorsocentrais e duas laterais; anepímero com uma fileira longitudinal irregular de sete cerdas; anepisterno e catepisterno nús. Garras simples, curvas próximo à metade de seu comprimento; empódio com cerca da metade do comprimento das garras (Fig. 4).


Figs 1-6. Clinodiplosis melissae, sp.n. (1) Macho, flagelômero $\mathrm{V}$; (2) fêmea, flagelômero V; (3) macho, asa; (4) macho, último tarsômero, perna I; (5) macho, genitália em vista dorsal; (6) fêmea, ovipositor em vista lateral.

Macho. Abdômen: tergitos 1-7 esclerotinizados, retangulares com uma única fileira de cerdas caudais e várias cerdas laterais; tergito 8 esclerotinizado, alongado, estreito e sem cerdas. Esternitos 1-8 retangulares, com cerdas distribuídas em toda a sua extensão, formando uma fileira caudal nítida. Terminália masculina: gonóstilo com 0,7 vezes o comprimento do gonocoxito, estriado, exceto na área basal setulosa; edeago delgado, arredondado no ápice e mais longo que o hipoprocto; hipoprocto bilobado e setoso; cerco com dois lobos com margem irregular e setoso, mais curto que o hipoprocto (Fig. 5).

Fêmea. Tergitos 1-7 e escleritos 2-7 esclerotinizados, retangulares, com cerdas distribuídas em toda a sua extensão, formando uma fileira na margem caudal. Tergito 8 como no macho. Esternito 8 e tergito 9 não esclerotinizados e sem cerdas. Esternito 9 não esclerotinizado, com cerdas distribuídas em toda sua extensão. Ovipositor alongado; cerco alongado, ovóide, setoso, com duas cerdas apicais mais espessas que as demais (Fig. 6).

Pupa. Comprimento total: 2,5-3,3 mm $(\mathrm{N}=5)$. Cabeça: chifres antenais nítidos e pouco proeminentes; espinhos frontais superior e inferior ausentes; arranjo de papilas cefálicas como na figura 7; cerda apical longa (Fig. 8). Tórax: espiráculo protorácico alongado, medindo $0,29 \mathrm{~mm}$, um pouco curvo, setiforme (Fig. 9). Abdômen: tergitos 2-8, no terço basal com duas fileiras transversais irregulares de espinhos de tamanho variado. 


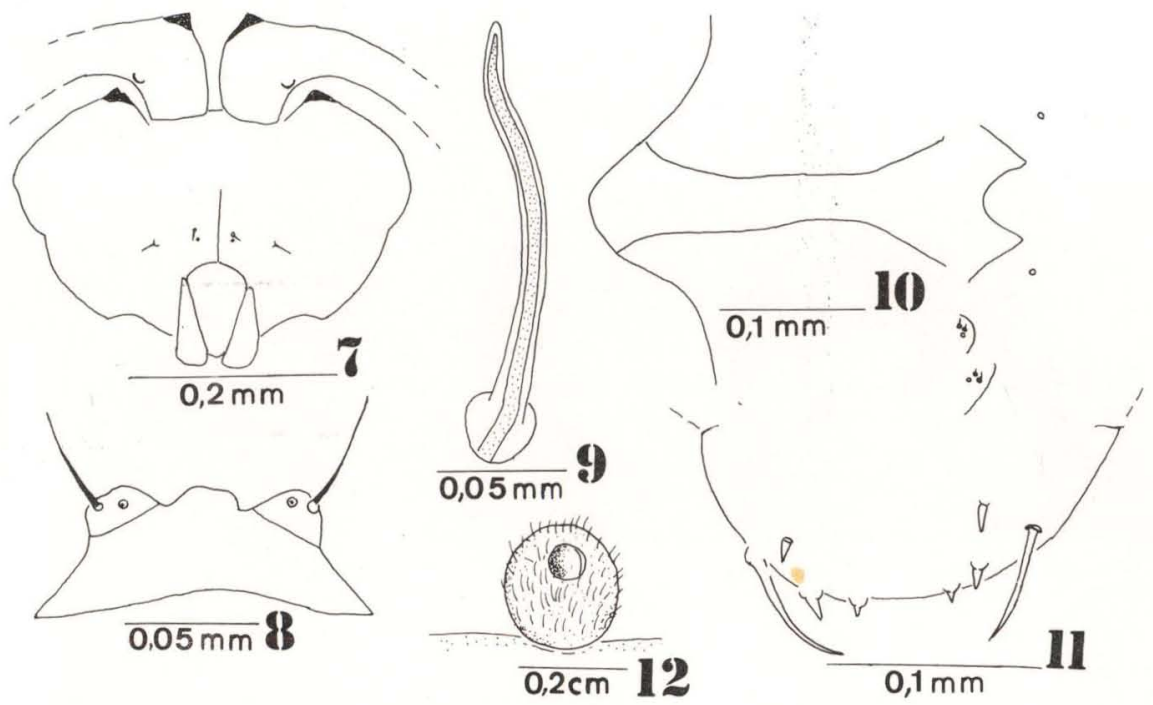

Figs 7-12. Clinodiplosis melissae, sp.n. (7) Pupa, região cefálica em vista ventral; (8) pupa, cerda apical; (9) pupa, espiráculo protorácico; (10) larva, espátula protorácica em vista vent ral; (11) larva, segmento terminal em vista dorsal; (12) galha, aspecto geral.

Larva. Comprimento total: 2,6-3,3 mm. Tórax: espátula protorácica bem desenvolvida com dois dentes triangulares no ápice; um par de papilas esternais não setosas; três pares de papilas laterais, dois setosas e um não setosa (Fig. 10). Abdômen: segmento terminal com quatro pares de papilas dispostos como na figura 11 e abertura anal em forma de fenda.

Holótipo macho. BRASIL: Rio de Janeiro, Maricá, 16-VII-1991, I. dos Santos leg., obtido de galhas em erva cidreira - Melissa officinalis L. (Labiatae). Parátipos: mesma procedência, data e coletor, duas fêmeas, cinco pupas e três larvas.

Galha. Esférica, verde, unilocular e foliar (Fig. 12).

AGRADECIMENTOS. Ao Dr. Raymond J. Gagné (Systematic Entomology Laboratory, USDA) pela ajuda na identificação do material.

\section{REFERÊNCIAS BIBLIOGRÁFICAS}

GAGNÉ, R.J. 1989. The Plant-Feeding Gall Midges of North America. Ithaca, Cornell University Press, 356p. 